much more than local importance. It has already afforded the magnetic staff of the Discovery a most valuable opportunity of comparing their instruments and practising their use in southern latitudes, of which they fully availed themselves, and when it comes to dealing with the magnetic data of the Antarctic expeditions, the Christchurch records should prove invaluable.

The public spirit and the appreciation of scientific aims shown by the New Zealand Government in providing the necessary funds for erecting and maintaining the observatory is of happy augury. It shows that war is not the only department in which the colony is anxious to come to the front.

Though hardly referred to in the "Report," mention may also be made of the fact that, prior to the erection of the observatory, Dr. Farr took magnetic observations with the instruments lent by the Royal Society at about I 50 stations scattered over New Zealand, about half in each of the two principal islands. This constitutes an important contribution to the complete magnetic survey of New Zealand, which Dr. Farr puts forward as part of the programme which he intends to prosecute as circum. stances allow. The objects which Dr. Farr has in view will meet with warm sympathy from all interested in the extension of our knowledge of terrestrial magnetism, and it is to be hoped that his efforts will meet with the continued support necessary for their complete realisation.

\section{Charles ChreE.}

\section{THE KEARTON SELBORNE. ${ }^{1}$}

GI

LBERT WHITE'S famous natural history classic has already seen something over eighty editions, and the appearance of yet another may be taken as a sure indication that its popularity shows no signs of waning. Indeed, in these days of "nature-teaching," it is quite likely to become, if possible, more widely read than ever, since there are few works in the English language better calculated to show the value of the intelligent use of the eyes or better suited to aid in the cultivation of the powers of observation. If anything could increase the popularity of one of the most popular books in the world, it would be the addition of illustrations of a modern type, faultless in execution and appropriate in subject. To furnish such pictures, no living artists, we venture to say, are better qualified than the Messrs. Kearton. Their success in this particular instance speaks, as usual, for itself; and we shall perhaps best serve the interests of both artists and publishers if we ask those of our readers who may be disposed to doubt our words to judge for themselves.

It should, however, be stated that this edition of White is a low-priced one, intended for the general public, and in no sense an édition de luxe. It is of small size and printed in small type, and most of the illustrations are therefore of necessity also on a rather microscopic scale. In the case of views of the village and the neighbouring country, such as that of old cottages on p. 88, this detracts but little, if at all, from their effectiveness; but it must be confessed that some of the photographs of bird-life, such as the one of an osprey and its nest on p. 78 , would have been improved had it been practicable to reproduce them on a somewhat larger scale.

In his introduction, the editor claims that the illustrations are in closer touch with the spirit of the author than any which have previously appeared, and this we can fully endorse. What, for instance, could better illustrate White's observations on the young cuckoo and its foster-parents than the exquisite photograph on

1 “"The Natural History of Selborne." By Gilbert White. With notes by R. Kearton and illustrations by $C$. and R. Kearton. Pp. xvi +294 (London: Cassell and Co., Ltd., 1902.) Price 6s. 6d.

NO. I 740 , voL. 67$]$ p. I 30 of a sedge-warbler watching one of these usurpers which has expelled the rightful occupants of the nest? Or what could be more appropriate to the author's account of the Selborne ring-ousels than the illustration (herewith reproduced) of these birds feeding their young?-an illustration actually taken in the Selborne country, which cost the Messrs. Kearton at least a week's watching to obtain. At the risk of being considered hypercritical, we cannot, however, refrain from mentioning that the photograph of swallows on a telegraph-wire (p. I39) is somewhat of an anachronism in an eighteenth.century work. Again, on p. 35, a figure of harvest-mice and their nest would have been much better than the one of common mice ; but perhaps to obtain the former was impossible even to a Kearton. We also think that a photograph of a fallow-buck with fully developed antlers should have replaced the one on p. 27 , in which these appendages are less than half-grown. In other respects, we have nothing but commendation to bestow on the illustrations, both as regards subject and execution.

Although brief, Mr. R. Kearton's notes are very much to the point, and give all the information required by ordinary readers in regard to modern emendations on White's zoological determinations. We note, however, that the editor has not seen fit to follow modern views in

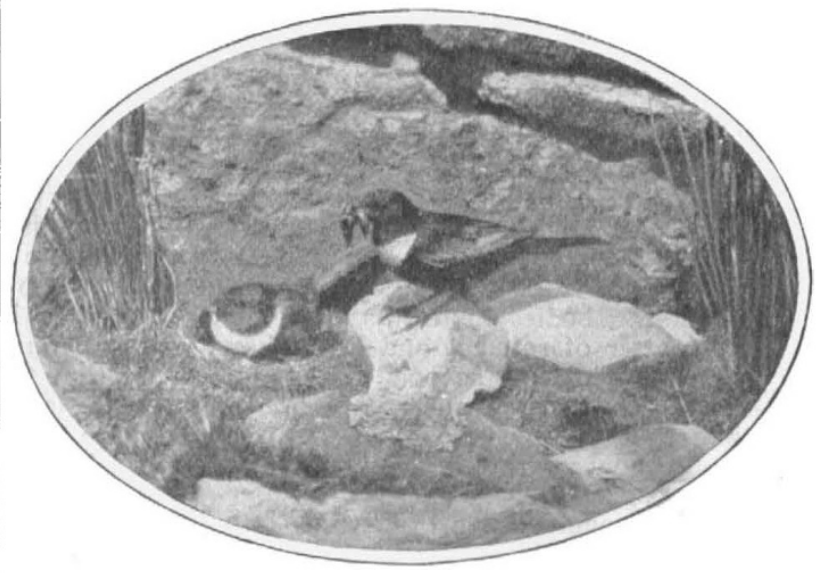

FIG. 1.-Ring-ousels eeding their young. From the Kearton "Selborne (Cassell and Co., Ltd.)

regard to the nomenclature of bats. The book appears singularly free from misprints (although we notice an unfortunate one on p. xiv.) and is admirably got up. It would be an insult to say that it is calculated to add to the Kearton reputation, since this is an impossibility, and we can do no more than commend it to the attention of all in search of an attractive gift-book.

R. L.

\section{RECENT CONFERENCES BETWEEN SCIENCE MASTERS AND EXAMINERS.}

DRING the past year or so signs have not been wanting that the unfortunate separation between teaching and examining, which has so often been deplored, is likely, before very long, to be either mended or ended. And we think that both the representatives of the Universities and the subcommittee of the Public School Science Masters' Association are to be congratulated on the new departures that were made at Cambridge on Saturday, February 7, and Oxford on Saturday, February I4, when they met at conferences summoned by the Vice-Chancellors of the respective Universities, to consider the question of entrance scholarships in the natural sciences given at the several 
colleges in Oxford and Cambridge, from the point of view of the teaching of science in public schools. For, though the representatives of the Universities did not accept all the proposals brought forward, they did accept a large proportion of the chief of them, as, for example, the proposal to limit the number of chief science subjects offered by any candidate to two, and another requiring all candidates offering geology, or biological subjects to show an acquaintance with the elements of chemistry and physics, and thus a real beginning in the direction of greater cooperation was made.

We do not, however, attach so much importance to the results attained by these first conferences as we do to the fact that the conferences were held at all. For we feel sure they will be followed by others, that the science masters will be imitated by the masters of other departments, and that whatever the immediate results may be, however great or however small, we might almost say however good or however bad, they will sooner or later-and we think sooner-do much to disentangle many knotty questions, and by generally improving the relations of those who teach and those who examine, do good work both for individuals and for the State, to both of whom the advancement of education is admittedly of vital importance. We hope and believe, moreover, that now the representatives of the colleges at Oxford and Cambridge have led the way in thus conferring directly with the assistant masters, who, in the nature of things, must do most of the actual teaching in the schools, other public bodies concerned with education, such as the University of London and the Civil Service Commissioners, will not be backward in promoting similar conferences whenever there may seem to be a reasonable prospect that they may prove useful. Some examining bodies in the past have been too timid in the matter of reform, and have shown far too much fear of giving the schools a lead, forgetting that the evil of going too slowly may be even greater, at times, than that of going too fast. Conferences like those we are now recording should be immensely helpful to such conservative bodies by giving them the best possible opportunities of getting into touch with the actual educators.

Hitherto, circumstances have tended far too much to make the teachers in schools look upon examiners solely as critics rather than as friends and colleagues. The recent action of the University of London in appointing schoolmasters to examine schoolboys, the proposed consultative committee to assist the War Office on educational questions, and these recent conferences at the old Universities, give good ground for hoping that this state of things is about to pass away, and that teachers and examiners will soon be pulling together more universally than they have done hitherto.

\section{NOTES.}

Dr. J. LARMOR, secretary of the Royal Society and Fellow of St. John's College, has been elected to the Lucasian professorship of mathematics at Cambridge, in succession to the late Sir George Stokes.

At a seismological congress held at Strasburg in April, r9or, statutes were proposed for an international seismological association. The German Government now invites delegates from various countries to meet to discuss these propositions. We learn from Science that this meeting will take place at Berne in May.

THE British and African Company's steamer Bornu, which arrived at Plymouth on February 27 , experienced a heavy

No. I 740 , voL. 67$]$ sand-storm on February 19, in latitude $27^{\circ}$ north, longitude $15^{\circ} 30^{\prime}$ west, that is, a little south of the Canary Islands. A tremendous sea prevailed for several hours, and so dense was the sand that it was impossible to see either end of the ship from the bridge.

Prof. КосH has been elected a Foreign Associate of the Paris Academy of Sciences, in succession to the late Prof. Virchow.

WE regret to see the announcement of the death of Prof. W. Harkness, astronomical director of the U.S. Naval Observatory, and Rear-Admiral (retired) of the United States Navy.

Prof. E. Mazelle has been appointed director of the Imperial Astronomical-Meteorological Observatory at Triest, Austria.

THE twenty-first congress of the Sanitary Institute will be held this year in Bradford, commencing on July 7 . The programme of arrangements made will be given in the supplement to the April Journal of the Institute.

Reuter states that a telegram has been received in New York from Mr. Aymé, the Lnited States Consul in Guadeloupe, stating that the French army engineers have established communication with Martinique by means of wireless telegraphy.

Reports from Mexico state that the volcano Popocatapetl has been bought up by a group of American financiers for the sum of $r, 000,000 l$. The idea is to utilise the valuable deposits of sulphur contained in the volcano, to get which it will be necessary to construct a railway to the summit.

DR. J. W. GREGory, F.R.S., professor of geology in the University of Melbourne, has met with an accident, necessitating an operation under chloroform. He was conducting scientific investigations in Tasmania at the time, and considerable anxiety has been felt concerning him. The latest news is, however, reassuring.

THE President of the Local Government Board states that the Royal Commission on Sewage Disposal is taking evidence and making investigations on the subject of dangerous contamination of shell-fish by sewage, with a view of ascertaining the measures necessary for obviating risk to the public health from this cause.

Mr. W. Bowman writes from Kansas City, Missouri, U.S.A., with reference to the flexure of a white marble slab mentioned in Nature of November 20, 1902 (p. 56) and November 27,1902 (p. 8x). He says that many years ago he saw at Windsor, Nova Scotia, in the churchyard of the old parish church, a marble slab bowed in the middle, exactly as described by our correspondents.

Mr. Henry Phipps has given Lord Curzon another 10,00ol. for the promotion of agricultural education or scientific research in India. Colonel Lockwood has been informed by the Secretary of State for India that, in view of the great benefits conferred on the European and the native community in India by the Pasteur Institute in the Punjab, the Viceroy proposes to apply half Mr. Phipps's gift to the establishment of a similar institute in Southern India.

IN the House of Commons on Tuesday the following resolution was moved :- " That the constitution of the Board of Trade has become obsolete, and this House is of opinion that a department presided over by a Minister of Commerce and Industry, having the status of a principal Secretary of State, should be substituted for the present offrce, to which should be entrusted all matters more particularly appertaining to commerce and industry, and to that end that an 